\title{
Population dynamics of mantis shrimp Harpiosquilla harpax and Oratosquillina sp. in the waters south of Madura Island, Indonesia
}

\author{
YENNI ARISTA CIPTA EKALATURRAHMAH ${ }^{1}$, ZAIRION $^{2,3, \boldsymbol{v}}$, YUSLI WARDIATNO ${ }^{2,3,4}$ \\ ${ }^{1}$ Program in Aquatic Resources Management, Graduate School, Institut Pertanian Bogor. Jl.Raya Dramaga, Kampus IPB Dramaga, \\ Bogor 16680, West Java, Indonesia \\ ${ }^{2}$ Department of Aquatic Resources Management, Faculty of Fisheries and Marine Sciences, Institut Pertanian Bogor. Jl Agatis No. 1, Kampus IPB \\ Dramaga, Bogor 16680, West Java, Indonesia. Tel.: +62-251-8622909, 8622911, Fax.: +62-251-8622907, ”email: zairion@ apps.ipb.ac.id, \\ yenni_arista@apps.ipb.ac.id \\ ${ }^{3}$ Center for Coastal and Marine Resources Studies, Institut Pertanian Bogor. J1. Raya Pajajaran, Kampus IPB Baranangsiang, Bogor 16143, West Java, \\ Indonesia \\ ${ }^{4}$ Environmental Research Center, Institut Pertanian Bogor. Jl. Raya Dramaga, Kampus IPB Darmaga, Bogor 16680, West Java, Indonesia
}

Manuscript received: 28 November 2019. Revision accepted: 16 March 2020.

\begin{abstract}
Ekalaturrahmah YAC, Zairon, Wardiatno Y. 2020. Population dynamics of mantis shrimp Harpiosquilla harpax and Oratosquillina $s p$. in the waters south of Madura Island, Indonesia. Biodiversitas 21: 1458-1466. Mantis shrimps are a potential fishery resource in Indonesia, but information about their population dynamics in the southern waters of Madura is limited. This study aimed to determine the population structure, growth, life span, and rate of exploitation for two taxa of mantis shrimp (Harpiosquilla harpax and Oratosquillina sp.). The research was conducted from September 2018 to February 2019 in the southern waters of Madura. The results showed that for $H$. harpax the majority of males caught ranged in length between 132.50 and $139.37 \mathrm{~mm}$ while the majority of females were between 153.45 and $160.22 \mathrm{~mm}$. For Oratosquillina sp., the majority of males caught ranged from 84.70 and $89.60 \mathrm{~mm}$ while the majority of females were between 89.85 and $95.30 \mathrm{~mm}$. The Growth Coefficient (K) for H. harpax was estimated to be 0.65 per year for males and 0.60 per year for females; while for Oratosquillina sp. the estimates were 0.81 and 0.78 per year, respectively. The $\mathrm{L}_{\infty}$ value for H. harpax males was $183.00 \mathrm{~mm}$ and for females $250.55 \mathrm{~mm}$, while the Lovalues for Oratosquillina sp. were $112.64 \mathrm{~mm}$ for males and 137.02 for females. The life span of $H$. harpax was estimated at 5 years, while for Oratosquillina sp. it was 4 years. The exploitation rate (E) for $H$. harpax males and females was 0.65 and 0.67 respectively, while for Oratosquillina sp. it was 0.54 and 0.58 . These estimations indicated overexploitation of the resource, particularly in the case of $H$. harpax.
\end{abstract}

Keywords: Exploitation rate, growth, life span, mantis shrimp, Southern waters of Madura

\section{INTRODUCTION}

Mantis shrimp is so named because its morphology and characteristics are similar to those of terrestrial mantis grasshoppers and praying grasshoppers. Taxonomically, mantis shrimp belongs to the order Stomatopoda within the class Malacostraca. There are 19 Stomatopoda families, grouped into five superfamilies, i.e. Bathysquilloidea, Squilloidea, Erythrosquilloidea, Lysiosquilloidea, and Gonodactyloidea. Altogether, more than 400 species of Stomatopoda have been identified and they are classified under 100 genera (Barber and Erdmann 2000). In the South China Sea, 116 stomatopod species from 51 genera have been identified within 13 families, classified into 4 superfamilies (Moosa 2000). Moreover, a number of new mantis shrimp species have been identified from Indonesian waters. They are Manningia misool found in Irian Jaya (Ahyong 1997), Harpiosquilla raphidea, and Oratosquillina gravieri found in Kuala Tungkal, District of Tanjung Jabung Barat, in the Province of Jambi (Mashar and Wardiatno 2011), and Haptosquilla glyptocercus, Gonodactyllelus annularis, Gonodactylus viridis, Chorisquilla hystrix found in the coastal waters of Pemuteran Bali (Pujawan et al. 2012).
Results of studies on the marine crustacean resource of Indonesia, including estimations of mantis shrimp populations, need to be disseminated to the public in order to facilitate sustainable management of these resources; i.e. to manage the harvest and prevent population decline (Hargiyatno et al. 2013). Priatna et al. (2014) argue that one of the requirements for correct fisheries management is data availability, especially accurate and reliable information on the fisheries resources to be utilized.

A review of several previous studies on mantis shrimps in Indonesia and the surrounding waters revealed a body of information on mantis shrimp biology (Wardiatno and Mashar 2010); spatial distribution of two types of mantis shrimps in Kuala Tungkal waters (Mashar and Wardiatno 2011); population dynamics of mantis shrimps in Kuala Tungkal in the Province of Jambi, Indonesia (Wardiatno and Mashar 2011); population dynamics of mantis shrimp O. gravieri in Pelabuhan Ratu Bay Waters (Ambarsari et al. 2016); and last but not least, on growth aspects of the giant mantis shrimp H. raphidea Fabricius, 1798 in Banten Bay, jn the Province of Banten (Mulyono et al. 2016). On the other hand, for the southern waters of Madura, there has never before been a formal investigation of the presence of mantis shrimps and of their population dynamics, even though previous studies have shown that mantis shrimp 
represents $14.8 \%$ of the total bottom trawl catch in those waters. The relatively large contribution of mantis shrimps in the catch of local fishermen emphasized the need for the investigation reported here. As such, the objective of this study was to analyze the population structure, growth rate, life-span, and exploitation level of mantis shrimps Harpiosquilla harpax and Oratosquillina sp. found in the southern Madura waters, and ultimately to provide a core of empirical data on which to base further studies for the sustainable management of these mantis shrimp resources.

\section{MATERIALS AND METHODS}

\section{Study area}

The study was conducted in the southern waters of Madura, in the Province of East Java, Indonesia. The observation sites consisted of three locations: i.e. station 1 located in the sub-district of Pangarengan and Mandangin Island in Sampang District; station 2 in the sub-district of Pademawu in Pamekasan District; and station 3 located in the sub-district of Bluto in Sumenep District (Figure 1). Monthly sampling of mantis shrimps was conducted from September 2018 to February 2019 in those three sampling areas.

\section{Procedures}

Both primary and secondary data were collected in the present study.
Primary data were collected from a field survey of the crop of mantis shrimps caught by local fishermen using a bottom trawl device in the southern waters of Madura. The samples were collected from 2-3 different fishermen in each location, and the entire harvest of mantis shrimps caught in the bottom trawls were subject to classification and measurement.

The main secondary data gathered in the investigation were estimates of sea surface temperatures obtained from Oceancolor.gsf.nasa.gov, processed using Aqua MODIS Imagery. This temperature data was incorporated in algorithms used to estimate natural mortality rate of the mantis shrimps. Sea surface temperature over the study period ranged from 29.48 to $31.76^{\circ} \mathrm{C}$, with an average temperature over the past two years of $30.21^{\circ} \mathrm{C}$. The average temperature was used in calculations of the shrimp natural mortality rates.

Sampling of mantis shrimp was representative of three different seasons; namely the South-East monsoon (September 2018); the first transition (October to November 2018); and the North-West monsoon (December 2018 to February 2019) (Figure 2).

The total number of mantis shrimps collected in the study was 1102; consisting of $690 \mathrm{H}$. harpax individuals and 412 Oratosquillina sp. individuals. The dimension and weight of each individual in the sample were measured and recorded. The shrimp length was measured using a caliper capable of measuring to the nearest $0.01 \mathrm{~mm}$, while the weight was measured using a digital scale capable of measuring to the nearest 0.01 grams.

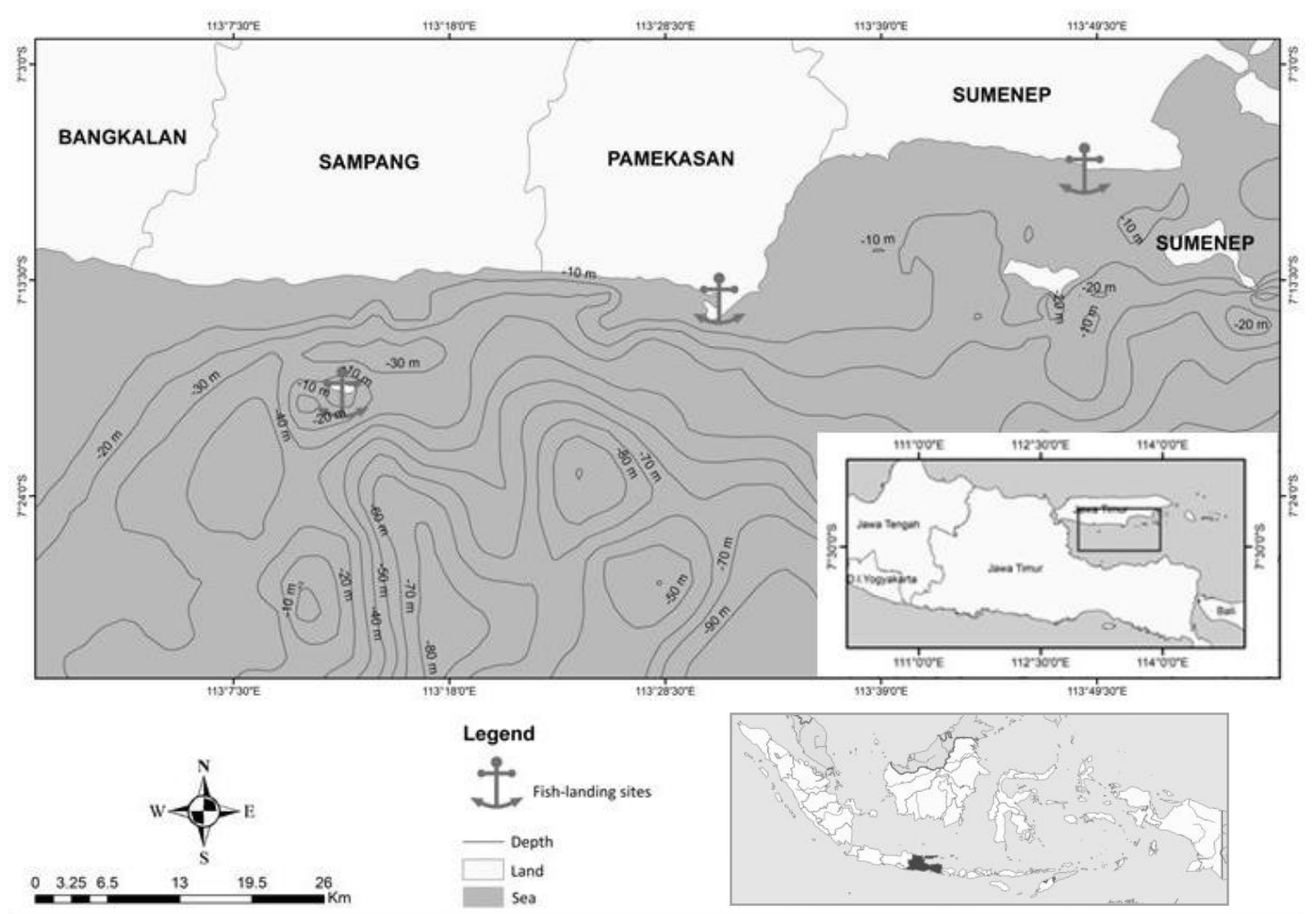

Figure 1. Mantis shrimp research locations in the southern waters of Madura, Indonesia 


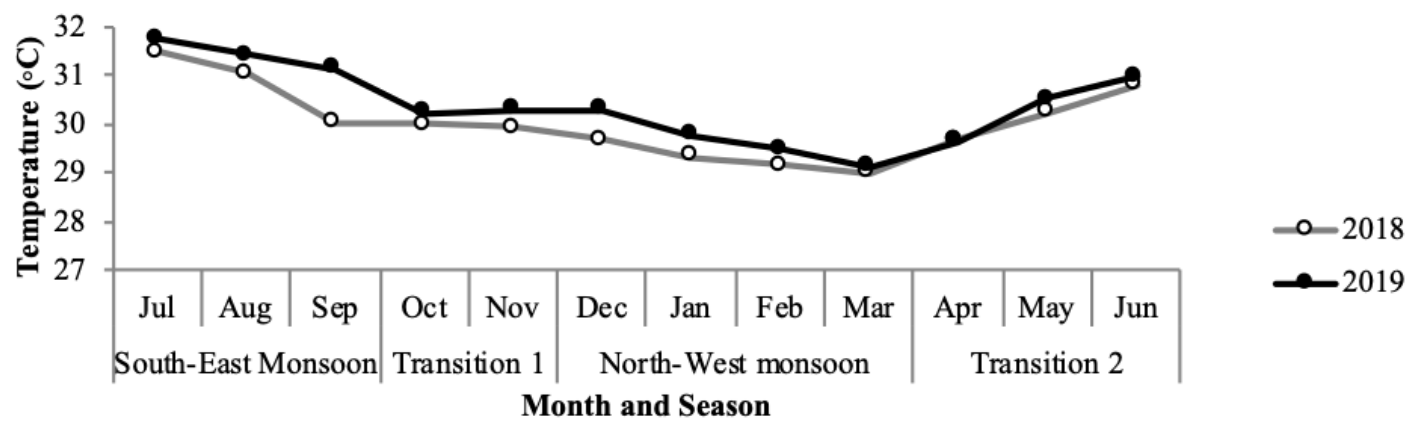

Figure 2. Sea Surface Temperature (SST) in the southern waters of Madura. Source: Aqua Modis Imagery

\section{Data analysis}

Sex ratio is the number of male shrimps divided by the number of female mantis shrimps collected from the catch. It was calculated using the following formula:

$$
\mathrm{NK}=\sum \mathrm{J} / \sum \mathrm{B}
$$

Where, NK is the sex ratio, $\sum \mathrm{J}$ is the number of male mantis shrimps, and $\sum \mathrm{B}$ is the number of female mantis shrimps.

Sex ratio balance tests (i.e. whether the ratios differed significantly from 1:1) were performed using the chisquare test $(\alpha=0.05)$.

The relationship between shrimps' weights and their lengths was determined using linear regression analysis on the logarithmically transformed data, according to the following formula:

$$
\log \mathrm{W}=\log a+b \log \mathrm{L}
$$

Where, $a$ is the intercept and $b$ is the slope.

Estimation of the mantis shrimps' growth parameters (i.e. the growth coefficient $\mathrm{K}$, and the asymptotic length $\mathrm{L}_{\infty}$ ) was obtained using the ELEFAN (Electronic LengthFrequency Analysis) I in the FiSAT program (FAOICLARM Fish Stock Assessment Tools) II version 1.2.2. This was based on the von Bertalanffy's growth model (Sparre and Venema 1999) as follows:

$$
\mathrm{L}_{\mathrm{t}}=\mathrm{L}_{\infty}\left[1-\mathrm{e}^{-\mathrm{K}(\mathrm{t}-\mathrm{t} 0)}\right]
$$

Where, $L_{t}$ is the length of a mantis shrimp (mm) at the age of $t, L_{\infty}$ is the theoretical maximum length or asymptotic length of a shrimp $(\mathrm{mm}), \mathrm{K}$ is the growth coefficient (mm/unit time), and $t_{0}$ is the theoretical age (month) when the shrimp's length (mm) is zero.

The value of $t_{0}$ was estimated using Pauly's equation as stated in Sparre and Venema (1999) as follows:

$$
\log \left(-\mathrm{t}_{0}\right)=-0.3922-0.2752\left(\log \mathrm{L}_{\infty}\right)-1.038(\log \mathrm{K})
$$

The estimated maximum age of a mantis shrimp was calculated using the following formula (Pauly 1983; Pradeep 2016):

$$
\mathrm{t}_{\max }=(3 / \mathrm{K})+\mathrm{t}_{0}
$$

Mantis shrimp mortality rates and exploitation levels were analyzed using the length-converted catch curve in FiSAT II package (Pauly 1983; Sparre and Venema 1999). Firstly, the rate of total mortality (Z) was estimated from the result of $\mathrm{K}$ estimation using von Bertalanffy's growth equation. Subsequently, the natural mortality rate (M) was estimated from the relationship between $\mathrm{M}$ and $\mathrm{L}_{\infty}, \mathrm{K}$ and the annual mean sea surface temperature $\mathrm{T}\left({ }^{0} \mathrm{C}\right)$, in accordance with Pauly's empirical equation (1980) as follows:

$$
\log (\mathrm{M})=-0.0066-0.2795 \log \left(\mathrm{L}_{\infty}\right)+0.6543 \log (\mathrm{K})
$$$$
+0.4634 \log (\mathrm{T})
$$

Fishing mortality (F) was determined by subtracting natural mortality $(\mathrm{M})$ from the total mortality $(\mathrm{Z})$; i.e. $\mathrm{F}=\mathrm{Z}$ - M. Finally, exploitation level (E) was calculated as the ratio of the fishing mortality $(\mathrm{F})$ to the total mortality $(\mathrm{Z})$; i.e. $\mathrm{E}=\mathrm{F} / \mathrm{Z}$ (Pauly 1983). The level of exploitation obtained was then compared to the optimum level; i.e. 0.5, according to Gulland (1971) in Pauly (1983).

\section{RESULTS AND DISCUSSION}

\section{Sex ratio}

The sex ratio of mantis shrimps $H$. harpax and Oratosquillina sp. caught in the southern waters of Madura varied from month to month throughout the study (Table $1)$. Based on monthly chi-square tests $(\alpha=0.05)$, we can see that the sex ratio for $H$. harpax was in a balanced state; i.e. in no month did the sex ratio differs significantly from 1:1. However, for Oratosquillina sp. in the month of January, the M:F sex ratio reached 1:1.66, and the chi-square test performed across all months indicated that there was a significant preponderance of females over males. The overall sex ratio in the current study was 1:0.98 and 1:1.26 
for H. harpax and Oratosquillina sp., respectively. In general, we can say that the sex ratio of mantis shrimp $H$. harpax was balanced, whereas the sex ratio of Oratosquillina sp. was unbalanced.

Differences in the sex ratios for the mantis shrimp from month to month can be caused by seasonal factors, spawning patterns, and behavior. Sea surface temperatures in the southern waters of Madura monthly fluctuated over the two years 2018-2019 (Figure 2). The average temperature for 2 years was $30.21{ }^{\circ} \mathrm{C}$; during the study period the water temperature ranged from $29.22-31.76^{\circ} \mathrm{C}$. Water temperature greatly affects the life of mantis shrimp.

\section{Body length-frequency distribution}

The frequency distribution for body length of $H$. harpax was unimodal, ranging from $55.31 \mathrm{~mm}$ to $237.56 \mathrm{~mm}$ (Figure 3). Classification of the data according to sex, showed that male mantis shrimps $H$. harpax ranged between $69.11 \mathrm{~mm}$ and $180.99 \mathrm{~mm}$ in length, while the females measured between $61.32 \mathrm{~mm}$ and $237.39 \mathrm{~mm}$ in length. Based on our classification of shrimp length into 26 classes, the modal class for male $H$. harpax was between $132.50 \mathrm{~mm}$ and $139.37 \mathrm{~mm}$, while the modal class for females was between $153.45 \mathrm{~mm}$ and $160.22 \mathrm{~mm}$ in length.

Figure 4 shows the frequency distribution of body length for Oratosquillina sp., wherein the shrimps' lengths ranged between $29.2 \mathrm{~mm}$ and $139.39 \mathrm{~mm}$. Classification of the shrimps lengths according to sex shows that the male mantis shrimps ranged between $29.2 \mathrm{~mm}$ and $104.51 \mathrm{~mm}$ in length, while the females ranged between $33.02 \mathrm{~mm}$ and $134.77 \mathrm{~mm}$. Based on our classification of shrimp length into 20 classes, the modal class for male Oratosquillina sp was between 84.70 and $89.60 \mathrm{~mm}$, while the modal class for females was between 89.85 and $95.30 \mathrm{~mm}$ in length.

\section{Length-weight relationship}

The entire sample of 1102 shrimps caught in the investigation, consisted of $690 \mathrm{H}$. harpax individuals and 412 Oratosquillina sp. individuals. The relationship between body length and weight measured on $H$. harpax shrimps is shown in Figure 5 in separate graphs, (i) for the 347 males and (ii) for the 343 females. For the Oratosquillina sp. shrimps, the relationships for 182 males and 230 females are shown in Figure 6.A and 6.B respectively.

The Mantis shrimp growth patterns could be determined from the value of $b$, the slope's value in the linear regression equation of the logarithmic relationship between body length and weight. For $H$. harpax, the equation of best fit for the length-weight relationship was $\mathrm{W}=0.0210 \mathrm{~L}^{2.3057}$ for the male shrimps and $\mathrm{W}=0.0163 \mathrm{~L}^{2.4302}$ for the female shrimps (Figure 5). Likewise, from the analysis of the length-weight relationship of the Oratosquillina sp. shrimps, we obtained equations of best fit of $\mathrm{W}=0.0405 \mathrm{~L}^{2.3090}$ for the males and $\mathrm{W}=0.0365 \mathrm{~L}^{2.4970}$ for the females (Figure 6).

Table 1. Sex ratio of mantis shrimps (Harpiosquilla harpax and Oratosquillina sp.) for each month throughout the study

\begin{tabular}{|c|c|c|c|c|c|c|c|c|c|c|}
\hline \multirow[b]{2}{*}{ Sampling period } & \multicolumn{5}{|c|}{ Harpiosquilla harpax } & \multicolumn{5}{|c|}{ Oratosquillina sp. } \\
\hline & $\mathbf{N}$ & Male & Female & $\begin{array}{c}\text { Sex ratio } \\
(\mathrm{M}: \mathrm{F})\end{array}$ & $x^{2}$ & $\mathbf{N}$ & Male & Female & $\begin{array}{c}\text { Sex ratio } \\
(\mathrm{M}: \mathrm{F})\end{array}$ & $x^{2}$ \\
\hline September 2018 & 56 & 21 & 35 & $1: 1.66$ & TS & 79 & 35 & 44 & $1: 1.25$ & TS \\
\hline October 2018 & 59 & 29 & 30 & $1: 1.03$ & TS & 63 & 28 & 35 & $1: 1.25$ & TS \\
\hline November 2018 & 192 & 107 & 85 & $1: 0,79$ & TS & 48 & 23 & 25 & 1:1.08 & TS \\
\hline December 2018 & 160 & 83 & 77 & 1:0.92 & TS & 57 & 26 & 31 & $1: 1.19$ & TS \\
\hline January 2019 & 122 & 65 & 57 & $1: 0.87$ & TS & 64 & 24 & 40 & 1:1.66 & $\mathrm{S}$ \\
\hline February 2019 & 101 & 42 & 59 & $1: 1.40$ & TS & 101 & 46 & 55 & $1: 1.19$ & TS \\
\hline Total & 690 & 347 & 343 & 1: 0.98 & TS & 412 & 182 & 230 & $1: 1.26$ & $\mathrm{~S}$ \\
\hline
\end{tabular}

Note: N: number of samples; M: male; F: female; S: significantly different; TS: Not significantly different

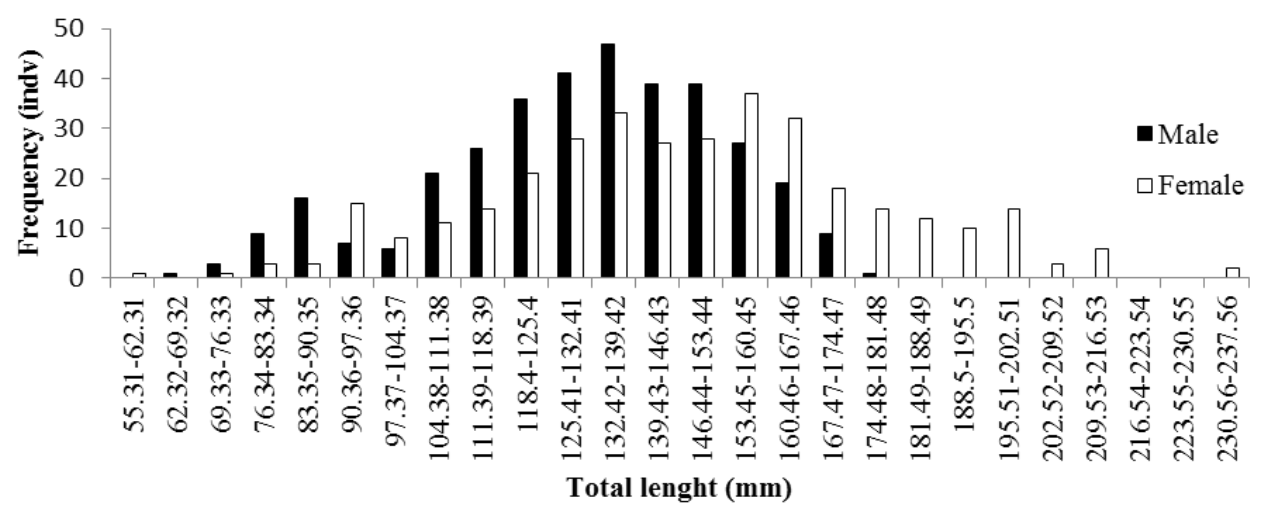

Figure 3. Length frequency distribution of mantis shrimp Harpiosquilla harpax caught in the southern waters of Madura, Indonesia 


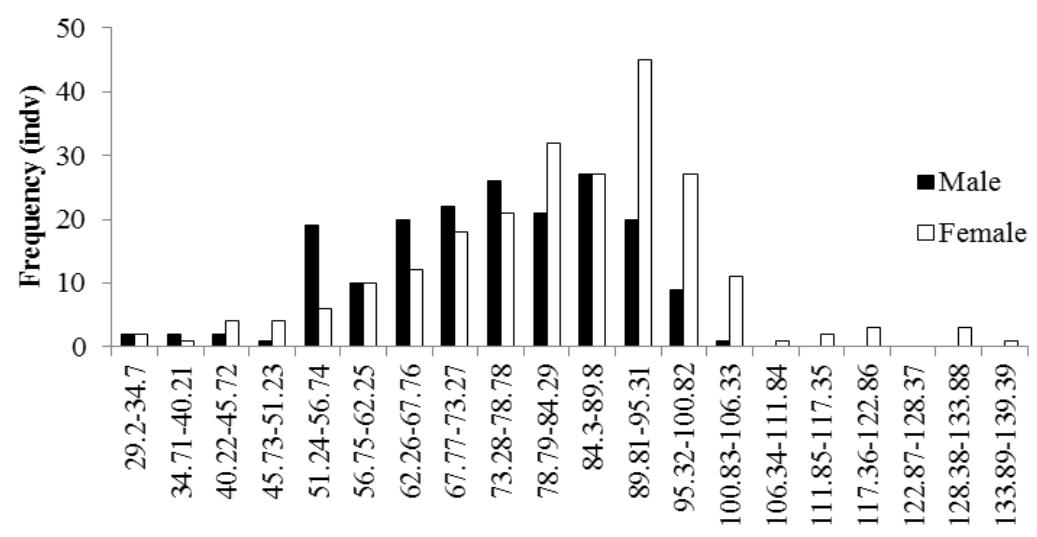

Total lenght(mm)

Figure 4. Length frequency distribution of mantis shrimp Oratosquillina sp. caught in the southern waters of Madura, Indonesia

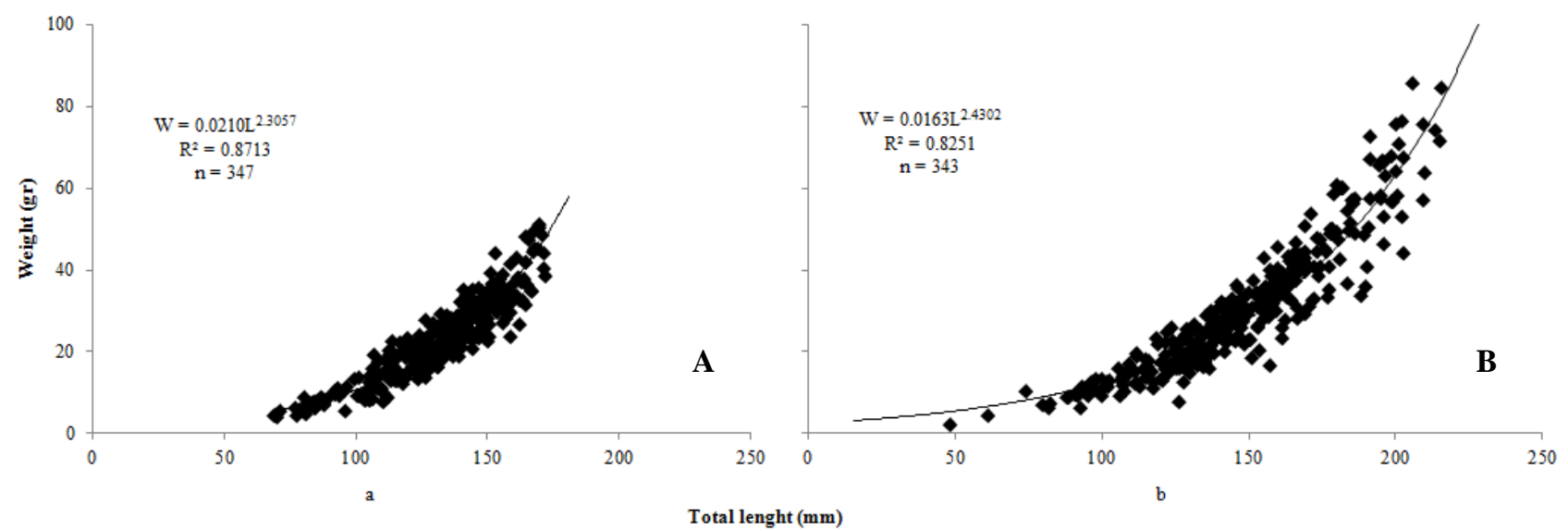

Figure 5. Length-weight relationship of mantis shrimp Harpiosquilla harpax caught in the southern waters of Madura, Indonesia: A. Male, B. Female

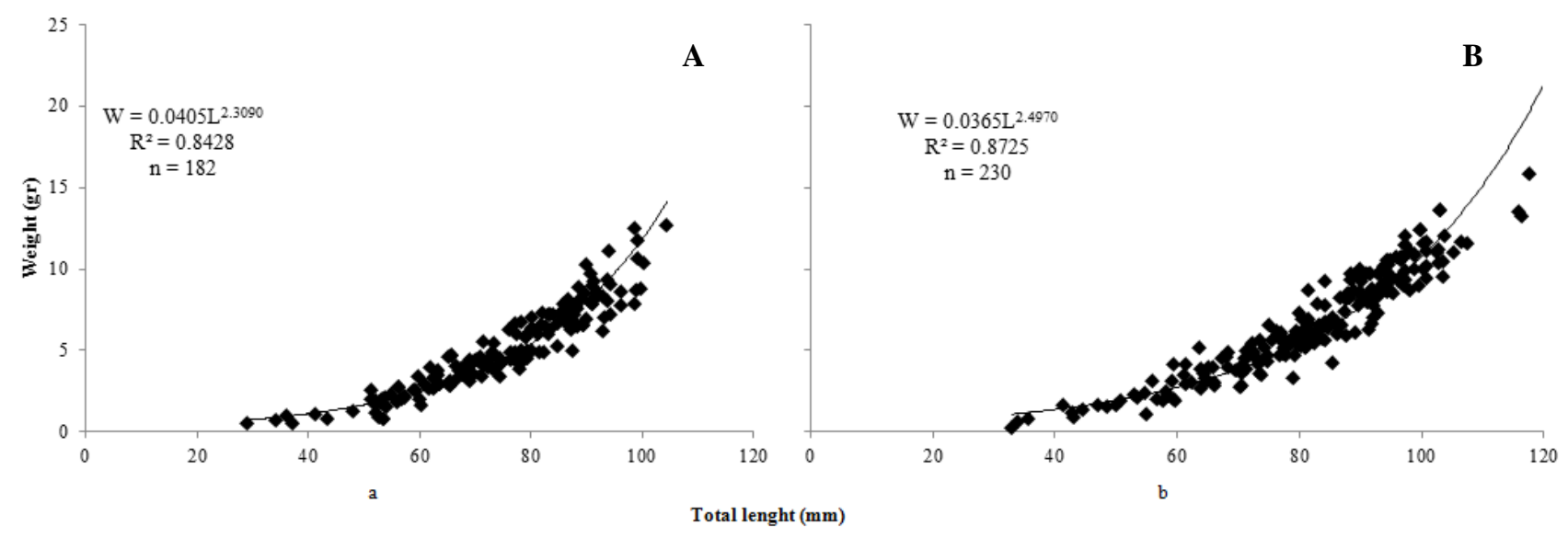

Figure 6. Length-weight relationship of mantis shrimp Oratosquillina sp. caught in the southern waters of Madura, Indonesia: A. Male, B. Female 


\section{Estimation of growth parameters}

Estimation of growth parameters encompasses calculation of the growth coefficient $(\mathrm{K})$; asymptotic length $\left(\mathrm{L}_{\infty}\right)$; and theoretical age of mantis shrimps when their total length is zero $\left(\mathrm{t}_{0}\right)$. Results of the analysis (in Table 2) revealed that male $H$. harpax shrimps had a higher growth coefficient $(\mathrm{K})$ but a lower asymptotic length $\left(\mathrm{L}_{\infty}\right)$ than the female shrimps.

This implies that the female H. harpax shrimps needed more time than the males to reach their asymptotic length $\left(\mathrm{L}_{\infty}\right)$. Analysis of the Oratosquillina sp. growth parameters revealed similar results.

The von Bertallanfy's growth equation model determined for male $H$. harpax mantis shrimps was $\mathrm{L}_{\mathrm{t}}=183$ $\left(1-\mathrm{e}^{[-0.65(\mathrm{t}+0.0377))]}\right)$ while for females it was $\mathrm{L}_{\mathrm{t}}=250.55\left(1-\mathrm{e}^{[-}\right.$ $0.6(\mathrm{t}+0.0362)])$. The relationship between the age of $H$. harpax shrimps and their total length is illustrated both for males and for females in Figure 7, in which, at the age of 0 years, the males were estimated to be $4.25 \mathrm{~mm}$ in length, while the females were $5.20 \mathrm{~mm}$. The life expectancy of a male $H$. harpax was estimated at around 54 months, while a female could be expected to live to 59 months.

The von Bertallanfy's growth equations determined for Oratosquillina sp. shrimps were $\mathrm{L}_{\mathrm{t}}=112.64\left(1-\mathrm{e}^{[-0.81}\right.$ $(\mathrm{t}+0.0733)])$ for the males and $\mathrm{L}_{t}=137.02\left(1-\mathrm{e}^{[-0.78(\mathrm{t}+0.0790)]}\right)$ for the females. The relationship between age and the total length of male and female Oratosquillina sp. is illustrated in Figure 8, where at the age of 0 years, the males were estimated to be $6.49 \mathrm{~mm}$ in length, while the females were estimated at $8.19 \mathrm{~mm}$ in length. Life expectancy of a male Oratosquillina sp. was estimated to be around 43 months, while a female could be expected to live to 45 months.

The growth curves in Figures 7 and 8 show that female H. harpax and Oratosquillina sp. shrimps need more time before they reach their asymptotic length $\left(\mathrm{L}_{\infty}\right)$ than the males. This is a result of $H$. harpax females having a smaller growth coefficient $(\mathrm{K})$, thus reaching their $\mathrm{L}_{\infty}$ later than the males. Moreover, energy obtained from food consumed by female mantis shrimps is prioritized for the formation and maturation of their gonads rather than for their own growth.

\section{Mortality rate and exploitation level}

The values for total mortality (Z), fishing mortality (F), and natural mortality (M) of mantis shrimps $H$. harpax and Oratosquillina sp. are presented in Table 3. Fishing mortality (F) of $H$. harpax is higher than that of Oratosquillina sp. both for the males and the females. Furthermore, the exploitation level (E) of $H$. harpax was estimated at 0.65 per year for males and 0.67 per year for females, or $30-33 \%$ above the theoretical optimum level; whereas for Oratosquillina sp., the exploitation level (E) was only 0.54 per year for males and 0.58 per year for females, i.e. $9-17 \%$ above the optimum level.

The rate of fishing mortality $(\mathrm{F})$ of $H$. harpax for both the male and female was higher than the natural mortality rate $(\mathrm{M})$. Furthermore, for male $H$. harpax the total mortality $(Z)$ was higher than for females; this suggests that the male mantis shrimp stock is more susceptible to death than the female.
Table 2. Estimation of mantis shrimp growth parameters

\begin{tabular}{lcccc}
\hline \multirow{2}{*}{ Growth parameter } & \multicolumn{2}{c}{ Harpiosquilla harpax } & \multicolumn{2}{c}{ Oratosquillina sp. } \\
\cline { 2 - 5 } & Male & Female & Male & Female \\
\hline $\mathrm{K}\left(\right.$ year $\left.^{-1}\right)$ & 0.65 & 0.60 & 0.81 & 0.78 \\
$\mathrm{~L}_{\infty}(\mathrm{mm})$ & 183.00 & 250.55 & 112.64 & 137.02 \\
$\mathrm{t}_{0}$ (year) & -0.0377 & -0.0362 & -0.0733 & -0.0790 \\
$\mathrm{t}_{\max }$ (month) & 54 & 59 & 43 & 45 \\
\hline
\end{tabular}

Table 3. Mortality rates and exploitation level of mantis shrimps (Harpiosquilla harpax and Oratosquillina sp.) in the southern waters of Madura

\begin{tabular}{lcccc}
\hline \multirow{2}{*}{ Parameter } & \multicolumn{3}{c}{ Mortality rates $\left(\right.$ year $^{-1}$ ) } \\
\cline { 2 - 5 } & \multicolumn{1}{c}{ Harpiosquilla harpax } & Oratosquillina sp. \\
\cline { 2 - 5 } & Male & Female & Male & Female \\
\hline Natural mortality (M) & 0.84 & 0.73 & 1.11 & 1.03 \\
Fishing mortality (F) & 1.57 & 1.47 & 1.33 & 1.44 \\
Total mortality (Z) & 2.41 & 2.20 & 2.44 & 2.47 \\
Exploitation (E) & 0.65 & 0.67 & 0.54 & 0.58 \\
\hline
\end{tabular}

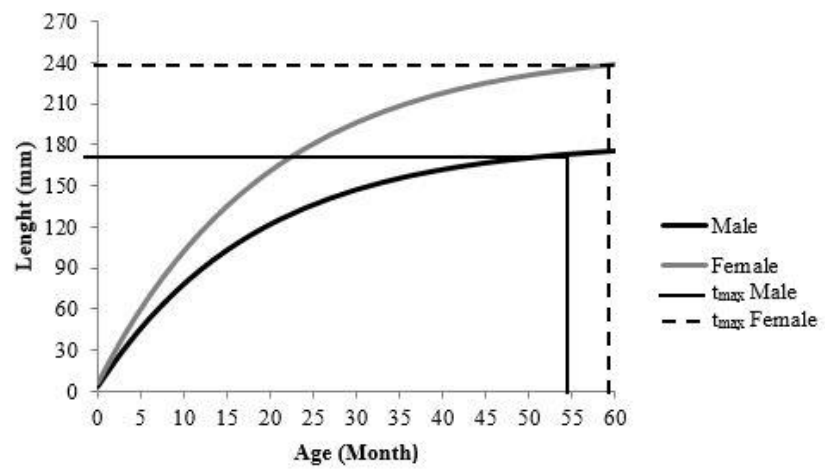

Figure 7. Relationship between the age and total length of Harpiosquilla harpax males and females in the southern waters of Madura based on the von Bertallanfy's growth equation

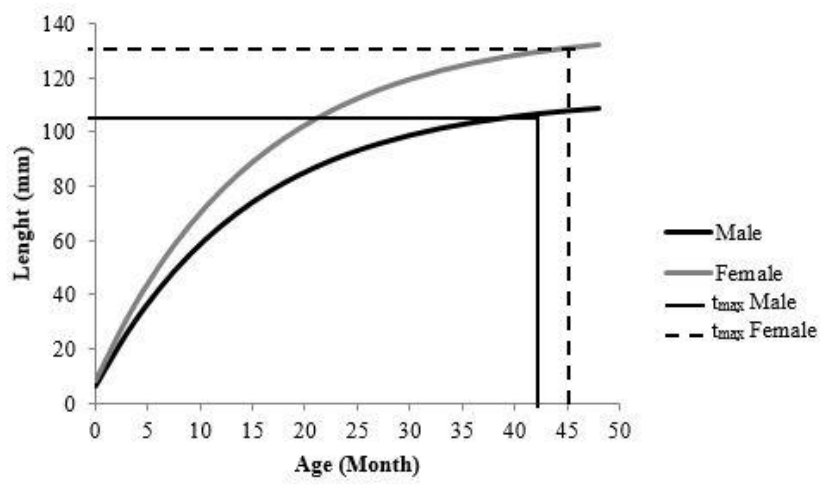

Figure 8. Relationship between the age and total length of Oratosquillina sp. males and females in the southern waters of Madura based on the von Bertallanfy's growth equation 
Similarly, the fishing mortality rate of mantis shrimps Oratosquillina sp. for both the males and females was higher than their natural mortality rate, but not as high as for $H$. harpax. The total mortality rate $(\mathrm{Z})$ of male Oratosquillina sp. mantis shrimps was the same as that of the females.

\section{Discussion}

Sex ratio is the ratio between male aquatic biota and female aquatic biota in a population. A ratio of $1: 1$, i.e. $50 \%$ males and $50 \%$ females, is seen as the ideal condition for species perpetuation (Bal and Rao 1984; Effendie 2002). From our calculations on the mantis shrimp catch in the southern waters of Madura, we obtained a sex ratio of 1: 0.98 for $H$. harpax and 1: 1.26 for Oratosquillina sp. The chi-square tests revealed that the sex ratio value of $H$. harpax mantis shrimps was in a balanced state, whereas for Oratosquillina sp. the sex ratio was unbalanced. This result is in line with previous studies by Djuwito et al. (2013) and Ambarsari et al. (2016) on mantis shrimps Oratosquilla oratoria in Cilacap and Oratosquilla gravieri in Pelabuhan Ratu Bay, which reported unbalanced sex ratios among the shrimps, of $1: 1.28$ and $1: 1.57$ respectively.

The population of harvested mantis shrimps $H$. harpax consisted of slightly more males than females (Table 1), and this is in line with the findings in a number of other studies that show the harvested crop of shrimps is mostly male shrimps (Wardiatno and Mashar 2011; Rao et al. 2015; Mulyono et al. 2016). On the other hand, the harvest of Oratosquillina sp. shrimps comprised significantly more females than males (Table 1); this is in line with the finding in a study by Kim et al. (2017) on O. oratoria in the coastal area of Tangyeong in Korea where most of the mantis shrimps caught were females.

Differences in the abundance of male and female mantis shrimp are influenced by seasons. This inference is supported by results of the study by Yan et al. (2015) on $H$. harpax in the Beibu Gulf of the South China Sea and by Kim et al. (2017) on $O$. oratoria in the coastal region of Tangyeong Korea. In those two pieces of research, male mantis shrimp were more common in the summer, while there were mostly female mantis shrimp in the winter. These results are explained by the fact that summer is a spawning period during which female mantis shrimps live in burrows to incubate their eggs (Hamano and Matsuura 1984).

According to Ahyong et al. (2008), mantis shrimp reach the maturity stage at a length of $10-30 \mathrm{~cm}$. On the other hand, Nakajima et al. (2010) reported that for Oratosquila oratoria, maturity started from $10 \mathrm{~cm}$. The sex ratio of the two species of mantis shrimp differed, which may be related to differences in the behavioral pattern of spawning. The genus Harpiosquilla spawns inside the nest, then the males leave the nest while the females stay in nest to incubate the eggs. Conversely, Oratosquilla spawns outside the nest and the males leave the nest to fertilize other females. The expectation is that the sex ratios for both mantis are in a balanced state. However, it is also preferred that female numbers are not less than or even more than males so that the populations in the wild can be maintained.

The difference in the number of shrimps in specific waters may be related to growth patterns, migration, and changes brought in by new shrimp species appearing among the existing populations. Moreover, Bal and Rao (1984) argue that imbalances in numbers of fish are related to their eating habits, spawning, or migration of particular types of fish. Simanjuntak et al. (2008) maintain that sexual patterns and sexual ratios vary quite a lot in a tropical region such as Indonesia. Unbalanced sex ratios are influenced by numerous factors including differences in behavior patterns, mortality rates, and growth rates (Effendie 2002).

With regard to the frequency distribution for body length, the modal class for H. harpax fell between 132.42 $\mathrm{mm}$ and $139.42 \mathrm{~mm}$ (Figure 3), while the modal class for Oratosquillina sp. fell between $89.81 \mathrm{~mm}$ and $95.31 \mathrm{~mm}$ (Figure 4). Mashar and Wardiatno (2011) reported that in their study the majority of mantis shrimps Oratosquilla garvieri were between $79 \mathrm{~mm}$ and $103 \mathrm{~mm}$ in length, presumably, because shrimps of that particular size had successfully adapted themselves to the environment.

According to Table 1, our collection of mantis shrimps traversed three different seasons namely the South-East Monsoon (September), First Transition (OctoberNovember), and North-West Monsoon (DecemberFebruary). The majority of mantis shrimps gathered from the September catch were smaller than the catch from the other months. This result was related to recruitment periods in the preceding months. Nakajima et al. (2010) reported that in the period of May-July the lengths of Oratosquilla mantis shrimps were $<10 \mathrm{~cm}$ in length, while in August the Oratosquilla were bigger (i.e. $>10 \mathrm{~cm}$ in length). This change in size presumably reflected changes in response to the spawning periods of Mantis shrimps (Kim et al. 2017).

The growth pattern of Mantis shrimps is referred to as negative allometric growth $(b<3)$. Analysis of the lengthweight relationship of mantis shrimps $H$. harpax and Oratosquillina sp. in our study shows that the growth patterns for these mantis shrimps, for both males and females, conformed to this negative allometric model. The similar growth patterns for the two types of mantis were presumably a consequence of resemblances in the characteristics of their environments (e,g. food supply and habitat).

Generally speaking, a negative allometric growth pattern in aquatic biotas is the result of overfishing, competition, and trophic potential (Mashar 2011; Arshad et al. 2015). Incidentally, the values of $b$ obtained from the current study differed from the value obtained in the study by Muzammil (2010) on mantis shrimp O. gravieri. Different $b$ values for the same fish species may be the results of different growth rates; age differences and stages of gonad development; food; sampling time; and water conditions (temperature and salinity) (Froese 2006; Tarkan et al. 2006; Jennings et al. 2001; Rahman et al. 2012). 
Table 4. Mantis shrimp growth parameters obtained in several studies in Indonesian and neighboring waters

\begin{tabular}{|c|c|c|c|c|}
\hline Species & $\begin{array}{c}\text { Growth } \\
\text { coefficient (year) }\end{array}$ & $\begin{array}{c}\begin{array}{c}\text { Asymptotic length } \\
(\mathbf{m m})\end{array} \\
\end{array}$ & Location & Author (s) \\
\hline Harpiosquilla harpax & $0.65(\mathrm{M}) ; 0.60(\mathrm{~F})$ & $183(\mathrm{M}) ; 250.55(\mathrm{~F})$ & Southern waters of Madura & Present study \\
\hline Harpiosquilla harpax & $1.10(\mathrm{M}) ; 0.75(\mathrm{~F})$ & $183.8(\mathrm{M}) ; 215.3(\mathrm{~F})$ & Perak, Peninsular Malaysia & Arshad et al. (2015) \\
\hline Harpiosquilla harpax & $0.89(\mathrm{M}, \mathrm{F})$ & $210(\mathrm{M}, \mathrm{F})$ & Vietnam & Dinh et al. (2010) \\
\hline Harpiosquilla raphidea & $1.68(\mathrm{M}) ; 1.32(\mathrm{~F})$ & $381.68(\mathrm{M}, \mathrm{F})$ & Kuala Tungkal, Jambi & Wardiatno and Mashar (2011) \\
\hline Oratisquilla gravieri & $0.23(\mathrm{M}) ; 0.37(\mathrm{~F})$ & $192(\mathrm{M}) ; 182.50(\mathrm{~F})$ & Palabuhanratu Bay waters & Ambarsari (2016) \\
\hline Oratosquilla oratoria & $0.82(\mathrm{M}) ; 0.72(\mathrm{~F})$ & $183.75(\mathrm{M}) ; 184.8(\mathrm{~F})$ & Tongyeong, Korea & Kim et al. (2017) \\
\hline Oratosquilla oratoria & $0.75(\mathrm{M}, \mathrm{F})$ & $191(\mathrm{M}, \mathrm{F})$ & Pesisir Hongkong & Pitcher et al. (1998) \\
\hline Oratosquillina sp. & $0.81(\mathrm{M}) ; 0.78(\mathrm{~F})$ & $112.64(\mathrm{M}) ; 137.02(\mathrm{~F})$ & Southern waters of Madura & Present study \\
\hline Squilla mantis & $1.6(\mathrm{M}) ; 1.3(\mathrm{~F})$ & $200(\mathrm{M}, \mathrm{F})$ & Ebro Delta & Abello and Martin (1993) \\
\hline
\end{tabular}

Note: M: male; F: female

Figures 7 and 8 show that mantis shrimps with different body length to age relationships have different $\mathrm{L}_{\infty}$ and $\mathrm{K}$ values. Table 4 lists growth coefficients $(\mathrm{K})$ and asymptotic lengths $\left(\mathrm{L}_{\infty}\right)$ for species of mantis shrimps obtained in a number of studies around Indonesian and neighboring waters. Different $\mathrm{L}_{\infty}$ and $\mathrm{K}$ values may be caused by intrinsic factors such as heredity, parasites, or diseases (Knaepkens et al. 2002) and/or by external factors such as temperature and food availability (Effendie 2002). Mantis shrimps with a smaller growth coefficient in Figures 7 and 8 are delayed in reaching their asymptotic length $\left(\mathrm{L}_{\infty}\right)$. Growth parameters estimated for a fish caught are influenced by the composition of the fish samples and by the analysis method (Widodo 1988). Moreover, growth parameters $\left(\mathrm{L}_{\infty}\right.$ and $\mathrm{K}$ ) of the same fish resources obtained from different locations may have different values. This can be caused by environmental conditions in the water at each location including food availability, water temperature, and oxygen saturation (Przybylski 1996; Tsoumani et al. 2006), as well as by fish size and gonad maturity (Merta 1992).

Life expectancy (lifespan) of mantis shrimps $H$. harpax and Oratosquillina sp. in this study was estimated based on the values of $\mathrm{K}$ and $\mathrm{t}_{0}$. Taylor (1958) in Pauly (1983) explains that lifespan is the age when the shrimp's length $\left(\mathrm{L}_{t}\right)$ reaches $95 \%$ of its estimated asymptotic length $\left(\mathrm{L}_{\infty}\right)$. Results of the lifespan calculations (Figures 6 and 7) show that the estimated life expectancy of H. harpax is less than 5 years, while Oratosquillina sp. will not exceed 4 years. Life expectancy for males is lower than for females (Table $2)$. The expected lifespans of mantis shrimps H. harpax and Oratosquillina $\mathrm{sp}$. are not that much different from lifespans determined for other mantis shrimp species; for example, Squilla mantis may reach 1.5 years (Abello and Martin 1993), Oratosquillina sp. 3.0 to 3.5 years (Hamano et al. 1987), Oratosquilla stephensoni around 2.5 years (Dell and Sumpton 1999), and H. raphidea from 6.7 to 8.5 years (Mashar 2011).

The rate of fishing mortality (F) of mantis shrimps $H$. harpax was estimated at 1.57 year $^{-1}$ for males and 1.47 year $^{-1}$ for females. For Oratosquillina sp. shrimps, the males (1.33 year-1) had lower fishing mortality than the females $\left(1.44\right.$ year $\left.^{-1}\right)$. The fishing mortality figure for $H$. harpax was 1.86 and 2.01 times higher than the natural mortality rate for males and females respectively; whereas for Oratosquillina sp. fishing mortality was 1.19 and 1.40 times higher than natural mortality for males and for females respectively. These figures indicate that in the southern waters of Madura more mantis shrimps $H$. harpax and Oratosquillina sp. die in fishing activities than as a result of natural causes.

According to Gulland (1971) in Pauly (1983), the optimum exploitation level (E) of fishery resources is 0.5 , which means that the natural mortality rate should be the same as the fishing mortality. A value of E greater than 0.5 indicates overexploitation of the particular resource. Exploitation level (E) of mantis shrimps $H$. harpax male was estimated at 0.65 year $^{-1}$ for males and 0.67 year $^{-1}$ for females and for Oratosquillina sp. it was 0.54 year $^{-1}$ in males and 0.58 year $^{-1}$ in females. The measured exploitation levels (E) of mantis shrimps exceeded optimum exploitation levels by $30 \%$ and $33 \%$ for $H$. harpax male and females respectively, and by $9 \%$ and $17 \%$ for Oratosquillina sp. male and females respectively. These figures clearly indicate that mantis shrimps in the southern waters of Madura are overexploited. Overexploitation of $H$. harpax could lead to "recruitment overfishing" as the majority of mantis shrimp were in mature stages of development. On the other hand, the possible overexploitation of Oratosquillina sp. is "growth overfishing" as most of the shrimps sampled in this study were small, with a preponderance of females.

\section{REFERENCES}

Abello P, Martin P. 1993. Fishery dynamics of the mantis shrimp Squilla mantis (Crustacea: Stomatopoda) population off the Ebro delta northwestern Mediterranean). Fish Res 16: 131-145.

Ahyong ST, Chan TY, Liao YC. 2008. A catalog of the mantis shrimp (Stomatopoda) of Taiwan. National Taiwan Ocean University, Keelung, Taiwan.

Ahyong ST. 1997. A new species of Manningia (Crustacea: Stomatopoda) from Irian Jaya, Indonesia, with remarks on the genus. Raffles Bull Zool 45 (2): 327-333.

Ambarsari N, Wardiatno Y, Krisanti M, Fahrudin A. 2016. Dinamika populasi udang mantis Oratosquillina gravieri (Crustacea: Stomatopoda) di perairan Teluk Palabuhanratu, Sukabumi, Jawa Barat. Jurnal Biologi Tropis 16 (1): 66-79. [Indonesian]

Arshad A, Sofea T, Zamri Z, Amin SMN, Ara R. 2015. Population dynamics of mantis shrimp, Harpiosqulla harpax in the costal waters of Pantai Remis, Perak, Peninsular Malaysia. Iran J Fish Sci 14 (1): $15-26$. 
Bal DV, Rao KV. 1984. Marine Fisheries. Tata McGraw-Hill Publishing Company, New Delhi, India.

Barber PH, Erdmann MV. 2000. Molecular systematics of the Gonodactylidae (Stomatopoda) using mitochondrial cytochrome oxidase c (subunit 1) DNA sequence data. J Crustac Biol 20 (5): 20 36.

Dell Q, Sumpton W. 1999. Stomatopod by-catch from prawn trawling in Moreton Bay, Australia. Asian Fish Sci 12: 133-144.

Dinh TD, Moreau J, Van MV, Phuong NT, Toan VT. 2010. Population dynamics of shrimps in littoral marine waters of the Mekong Delta South of Vietnam. Pak J Biol Sci 13 (14): 683-690.

Djuwito, Saputra SW, Widyaningtiwi WA. 2013. Beberapa aspek biologi udang mantis (Oratosquilla oratoria De Haan, 1844) di perairan Cilacap, Jawa Tengah. J Manag Aquat Resour 2 (3): 56-64. [Indonesian]

Effendie MI. 2002. Biologi Perikanan. Yayasan Pustaka Nusantara, Yogyakarta, Indonesia. [Indonesian]

Froese R. 2006. Cube law, condition factor and weight length relationships: history, meta-analysis and recommendations. J Appl Ichthyol 22 (4): 241-253.

Hamano T, Matsuura S. 1984. Egg laying and egg mass nursing behaviour in the Japanese mantis shrimp. Bull Jpn Soc Sci Fish 50 (12): 19691973.

Hamano T, Morrissy NM, Matsuura S. 1987. Ecological information on Oratosquilla oratoria (Stomatopoda, Crustacea) with an attempt to estimate the annual settlement date from growth parameters. J Shimonoseki Univ Fish 36 (1): 9-27.

Hargiyatno IT, Sumiono B, Suharyanto. 2013. Laju tangkap, kepadatan stok dan beberapa aspek biologi udang jerbung (Penaeus merguiensis) di perairan Dolak, Laut Arafura. Bawal 5 (2): 123-129. [Indonesian]

Jennings S, Kaiser MJ, Reynolds JD. 2001. Marine Fisheries Ecology Blackwell Science Ltd., London (UK).

Kim SE, Kim H, Bae H, Kim HG, Oh CW. 2017. Growth and reproduction of the Japanese mantis shrimp, Oratosquilla oratoria (de Haan 1844) in the Coastal Area of Tongyeong, Korea. Ocean Sci J 52 (2): 257-265.

Knaepkens G, Knapen D, Bervoets L, Hanfling B, Verheyen E, Eens M. 2002. Genetic diversity and condition factor: a significant relationship in Flemish but not in German populations of the European bullhead (Cottus gobio L.). Heredity 89: 280-287.

Mashar A, Wardiatno Y. 2011. Distribusi spasial udang mantis Harpiosquilla raphidea dan Oratosquillina gravieri di Kuala Tungkal, Kabupaten Tanjung Jabung Barat, Provinsi Jambi. Jurnal Pertanian-UMMI 1 (1): 41-46. [Indonesian]

Mashar A. 2011. Pengelolaan Sumberdaya Udang Mantis (Harpiosquilla raphidea Fabricius, 1798) Berdasarkan Informasi Biologi di Kuala Tungkal, Kabupaten Tanjung Jabung Barat, Jambi. [Tesis]. Sekolah Pascasarjana, Institut Pertanian Bogor, Bogor. [Indonesian]

Merta IGS. 1989. Dinamika populasi ikan cakalang, Katsuwonus pelamis Linnaeus 1758 (Pisces : Scombridae) dari perairan Sumatera Barat. Jurnal Penelitian Perikanan Laut 53: 33-48. [Indonesian]

Moosa MK. 2000. Marine biodiversity of the South Chine Sea: A Checklist of Stomatopod Cructacea. Raffles Bull Zool Suppl 8: 405 457.

Mulyono M, Patria MP, Abinawanto, Affandi R, Heriyansyah FA. 2016 Growth aspect of giant mantis shrimp Harpiosquilla raphidea Fabricius, 1798 Banten Bay Waters, Banten Province. Int J Mar Sci 6 (32): $1-14$

Muzammil W. 2010. Studi Morfometrik dan Meristik Udang Mantis (Oratosquillina gravieri dan Harpiosquilla raphidea) di Daerah Pantai Berlumpur Kuala Tungkal, Provinsi Jambi. [Skripsi]. Fakultas Perikanan dan Ilmu Kelautan, Institut Pertanian Bogor, Bogor. [Indonesian]

Nakajima M, Kodama K, Horiguchi T, Tanaka Y, Shiraishi H. 2010 Impacts of shifts in spawning seasonality and size at maturation on the population growth of mantis shrimp in Tokyo Bay. Mar Ecol Prog Ser 418: 179-188.

Pauly D. 1980. On the interrelation between natural mortality, growth parameter, and mean environmental temperature in 175 fish stock. Conseil International pour L'Exploration de la Mer. J du Conseil 39: 175-195.

Pauly D. 1983. Fish Population Dynamics in Tropical Waters: A Manual for Use with Programmable Calculator. ICLARM Studies and Reviews 8. International Center for Living Aquatic Resources Management, Manila (PH).

Pitcher TJ, Watson R, Courtney A, Pauly D. 1998. Assessment of Hong Kong's Inshore Fishery Resources. Fisheries Centre, University of British Columbia, Vancouver (CA).

Pradeep HD. 2016. Age, growth and mortality of Lutjanus vitta (Quoy \& Gaimard, 1824) off Madras coast along south-east coast of India. Int J Fish Aquat Stud 4 (5): 183-188.

Priatna A, Purbayanto A, Simbolon D, Hestirianoto T. 2014. Kemampuan tangkap jaring trawl terhadap ikan demersal di perairan Tarakan dan sekitarnya. Jurnal Penelitian Perikanan Indonesia. 20 (1): 19-30. [Indonesian]

Przybylski M. 1996. Variation in fish growth characteristics along a river course. Hydrobiology 325: 39-46

Pujawan AANO, Nindhia TS, Mahardika IGNK. 2012. Identifikasi spesies udang mantis (Stomatopoda) di perairan Pemutaran dengan menggunakan gen cytochrome $\mathrm{C}$ oxidase subunit-1 dari DNA mitokondria. Indonesia MedicusVeterinus 1 (2): 268-280. [Indonesian]

Rahman MM, Hossain MY, Hossain MA, Ahamed F, Ohtomi J. 2012. Sex ratio, length-frequency distribution and morphometric relationship of length-length and length-weight for spiny eel, Macrognathus aculeatus, in the Ganges River, NW Bangladesh. World J Zool 7 (4): 338-346.

Rao PY, Prasad DR, Sirisha IR, Rao MS, Teja G. 2015. Meat yield studies in Harpiosquilla harpax (de Haan, 1844) and Oratosquilla anomala (Tweedie, 1935) (Crustacea: Stomatopoda) represented in the shrimp trawl net by-catches off Visakhapatnam, east coast of India. Eur J Exp Biol 5 (5): 6-11

Simanjuntak CPH, Rahardjo MF, Sukimin S. 2008. Musim pemijahan dan fekunditas ikan selais (Ompok hypophthalmus) di rawa banjiran Sungai Kampar Kiri, Riau. J Fish Sci 10 (2): 251-260. [Indonesian]

Sparre P, Venema SC. 1999. Introduksi Pengkajian Stok Ikan Tropis. Badan Penelitian dan Pengembangan Perikanan. Jakarta (ID). Terjemahan dari: Introduction to Tropical Fish Stock Assessment. FAO Fish Tech.

Tarkan AS, Gaygusuz O, Acipinar P, Gursoy C, Ozulug M. 2006. Lengthweight relationship of fishes from the Marmara region (NW-Turkey). J Appl Ichthyol 22 (4): 271-273.

Tsoumani M, Liasko R, Moutsaki P, Kagalou I, Leonardos I. 2006. Length-weight relationships of an invasive cyprinid fish (Carassius gibelio) from 12 Greek lakes in relation to their trophic states. J Appl Ichthyol 22: 281-284

Wardiatno Y, Mashar A. 2010. Biological information on the mantis shrimp, Harpiosquilla raphidea (Fabricius 1798) (Stomatopoda, Crustacea) in Indonesia with a highlight of its reproductive aspects. J Trop Biol Conserv 7: 65-73.

Wardiatno Y, Mashar A. 2011. Population dynamics of the Indonesian mantis shrimp, Harpiosquilla raphidea (Fabricius 1798) (Crustacea: Stomatopoda) collected from a mud flat in Kuala Tungkal, Jambi Province, Sumatera Island. Ilmu Kelautan 16 (2): 111-118. [Indonesian]

Widodo J. 1988. Population dynamics and management of ikanlayang, Decapterus spp (Carangidae) in the Java Sea. Jurnal Penelitian Perikanan Laut 47: 11-44. [Indonesian]

Yan Y, Zhang Y, Wu G, He X, Zhao C, Lu H. 2015. Seasonal feeding habits, reproduction, and distribution of Harpiosquilla harpax (Stomatopoda: Harpiosquillidae) in the Beibu Gulf, South China Sea. J Crustac Biol 35 (6): 776-784. 